\title{
Review about Online Educational Guidance during the COVID-19 Pandemic
}

\author{
Iván Mielgo-Conde, Sara Seijas-Santos and Mario Grande-de-Prado *(D)
}

Citation: Mielgo-Conde, I.;

Seijas-Santos, S.; Grande-de-Prado, M. Review about Online Educational

Guidance during the COVID-19

Pandemic. Educ. Sci. 2021, 11, 411.

https://doi.org/10.3390/

educsci11080411

Academic Editors: Angelos Sofianidis, Maria Meletiou-Mavrotheris,

Konstantinos Katzis, Nayia

Stylianidou and Panagiota

Konstantinou-Katzi

Received: 1 July 2021

Accepted: 6 August 2021

Published: 9 August 2021

Publisher's Note: MDPI stays neutral with regard to jurisdictional claims in published maps and institutional affiliations.

\section{Copyright: (c) 2021 by the authors.} Licensee MDPI, Basel, Switzerland. This article is an open access article distributed under the terms and conditions of the Creative Commons Attribution (CC BY) license (https:// creativecommons.org/licenses/by/ $4.0 /)$.
Facultad de Educación, Universidad de León, 24071 León, Spain; imielc00@estudiantes.unileon.es (I.M.-C.); sseijs00@estudiantes.unileon.es (S.S.-S.)

* Correspondence: mgrap@unileon.es

\begin{abstract}
The COVID-19 pandemic has affected almost every area of our lives. It meant a break from our lifestyles, transforming everything from face-to-face to online. Among the places where this situation has become more evident are primary schools, secondary schools, and universities, which have had to adopt online teaching in its entirety. Faced with this situation, the work of the educational counsellors was essential to coordinate the centre with the families and to enable students to follow the classes in the best way possible. The objective of this study is to analyse the scientific literature about online educational guidance, with a focus on the COVID-19 pandemic. To achieve this, a scoping review inspired by the PRISMA model was done. A total of 42 articles were studied. The main results show that many counsellors were at a disadvantage and in a very stressful situation, as they did not have the necessary digital training. On the other hand, this situation has been the first contact for many counsellors with the use of ICT within their profession and in an unexpected situation, without time for training or enough preparation.
\end{abstract}

Keywords: COVID-19; counselling; online educational guidance; ICT

\section{Introduction}

The year 2020 will always be remembered as the year when the world came to a virtual standstill. At the end of 2019, there was an epidemic outbreak in the Chinese city of Wuhan caused by SARS-CoV-2, better known as COVID-19. This virus spread rapidly around the world, and the World Health Organisation (WHO) declared this spread as a health emergency of international concern on 30 January 2020; on 11 March 2020, it was recognised as a pandemic [1].

To curb the spread of the virus, most countries around the world opted for containment as the main measure. For instance, in Spain, a state of alarm was declared in March of 2020, with a series of measures involving the closure of all non-essential activities [2], the adoption of teleworking in companies [3] and the closure of schools [4].

Because of the closure of the schools, there was a radical change in teaching methods, replacing face-to-face teaching with online teaching. This was a change that was very sudden, without the option of being able to prepare or plan resources or tools for the correct development of teaching. Digital competence was a very important factor at this time, as both school staff and pupils had to cope solely using technology.

Teachers and educational counsellors had to adapt how they taught and be able to get in touch with the students in the schools. The search for online resources to be able to continue teaching in the best possible way became essential, even more so for educational counsellors, who in many cases were unable to provide the desired follow-up for pupils who needed it.

The adoption of this teaching method created an inequality among the student body. Many students were very negatively affected by this situation due to a lack of electronic devices or Internet connection to be able to adequately follow the development of e-learning. 
In many families, this lack of devices was due to the limited number of devices owned, as they are shared among family members [5].

The suspension of face-to-face teaching meant that young people had to isolate themselves from others at home. This isolation led to trauma, which in some cases worsened into much more serious problems [6] and led to uncertainty about the future for students [5].

The work of the educational counsellors was crucial, as in addition to the development of their professional competencies they had to contact families who had no way to adequately follow the online teaching. Moreover, the mental health of students was affected by the uncertainty of this global pandemic, and the work of the educational counsellor was very important.

The online guidance carried out during the lockdowns resulting from the COVID-19 expansion is a topic that is still very much alive in the scientific literature, as it brings up a lot of results in platforms such as Scopus (741 results), Web of Science (619 results) or Dialnet (101 results) although it is a topic that has been in existence for little more than a year.

Moreover, it is a subject that arouses great interest in a society as digitalised as the one in which we live. COVID-19 is particularly relevant, as we are still immersed in this global pandemic. We must live with the consequences it has caused in our society with the uncertainty of how it will evolve and with the problems that continually arise with the vaccination against this virus carried out in different countries [7].

\section{Theoretical Framework}

The role of technology in education has been gaining importance over the years and its use in classrooms is becoming increasingly relevant [8]. Due to the COVID-19 pandemic, the education system as well as many other areas are being disrupted. Among the most prominent measures in response to this situation is the suspension of face-to-face education and its replacement by distance education [9].

The role of the educational counsellor is a very important one within the education of young people, especially in this pandemic context, where their skills have been much needed at a time when many people were experiencing personal difficulties [10]. During the lockdowns, both teachers and guidance professionals were overwhelmed by this situation of sudden change, unable to provide the personalised attention that many learners needed and forced to suspend specialised support in certain areas [11]. Psycho-pedagogical evaluations were impossible, being temporarily unadministrable, and psycho-pedagogical reports could be produced only for students who had already been evaluated [12].

This pandemic has marked the era of using the Internet as a tool for learning, and counsellors have found themselves in the position of performing counselling services to promote self-care and well-being among students during the confinement resulting from the spread of this virus [13]. Although this situation has forced the adaptation of online counselling services to online resources, online counselling is not a new phenomenon and has been used for years [14].

The use of Information and Communication Technology (hereafter ICT) is increasing. The use of ICT is widespread among young people, with instant messaging, consumption of multimedia content, as an important source of entertainment and for exploring the educational opportunities available to them [15]. Because of this, ICT has become essential for the development of guidance over the years [16]. The use of ICT in schools allows the optimisation and management of the work in a more efficient way and reduces the costs of the process, as well as enabling students to learn and master technological tools that make them comfortable with virtual education [17]. Online counselling is a good alternative for counsellors to prevent, reduce and fix problems [18].

The use of ICT in educational guidance has many advantages in terms of interaction, access to information, flexibility in problem orientation, optimisation of the guidance action, the autonomy gained by the user and the personal and professional development of the participants. However, it also has disadvantages, such as the lack of basic digital literacy, 
the loss of personal communication elements or the quality of the materials and resources to be used [19].

The use of ICT in the guidance process strengthens the role of the educational counsellor [19]. An example of a digital tool that has been used within the field of guidance, more specifically within career guidance, is the MyWaypass platform. According to Suárez [20], it is a flexible platform that can be easily integrated into schools within the Academic and Vocational Guidance Plans (hereafter, POAP). Among the frequently used programmes, SIGI, DISCOVER and the CHOICES system can also be highlighted [19].

According to research conducted by Budianto et al. [21], another good example of the use of ICT in the field of guidance is instant messaging applications. The research concludes that, with the right optimisation in the use of these popular applications, counsellors can help teachers to solve guidance-related problems with greater accuracy.

The educational counsellor needs to innovate to adequately apply ICT in the counselling process [8], but it seems that, faced with this difficult situation, counsellors do not adequately optimise technology in the counselling process [22]. One of these reasons may be a lack of knowledge and confidence in ICT on the part of counsellors; the correct performance of these tasks depends above all on both initial and continuous training of guidance practitioners [9]. Digital literacy is a great ally for school counsellors, since in this way meaningful digital resources can be used and created for students [23]. Moreover, if digital literacy is maximised, counsellors could be more innovative in thinking about resources [24]. The digital competence of educational counsellors has been studied in these articles, although it is not very abundant in the scientific literature, because, until 2020, with the onset of the pandemic, the use of the technology in this area was not widespread.

The key to digital transformation in schools is its acceptance by guidance counsellors. Without acceptance, the guidance counsellor will not be able to optimise the use of technology and may negatively affect students' motivation [8]. Furthermore, the institution itself must support counsellors to be trained and to implement technology in their practice, as according to Maurya et al. [25], there are currently very few counselling training programmes on the practice of technology use that go beyond minimal exposure to technology.

According to Košir et al. [26], factors such as counsellors' self-perceived self-efficacy concerning ICT, their attitude towards online counselling and even the support of their superiors had a significant impact on counsellors' stress levels. This study also found that educational counsellors who experienced low levels of work-related stress from online counselling perceived themselves as being able to handle ICT efficiently with a positive predisposition towards the use of ICT and they also had a high level of support from their superiors.

In a study conducted by Foon et al. [27], it was concluded that educational counsellors felt more comfortable and self-confident when they had a room with electronic devices to carry out their work. According to this study, the intention of counsellors to use ICT in educational guidance processes was mostly affected by the level of technological competence and the background of the counsellors in terms of "training" in online guidance. Previous studies have already shown that adequate professional development is essential to overcome the barrier to the application of ICT within schools [28]. It is evident that educational counsellors prefer face-to-face counselling because it is easier to focus on the gestures and facial expressions of students in a private environment where they are in control. It is also preferred because technology-related mishaps, which can lead to fatigue in the counsellor's work, cannot occur. On the other hand, the same respondents say that online counselling is surprisingly efficient.

Because of this rapid adaptation and shift towards the full use of ICTs, educational counsellors who have provided services for the duration of the COVID-19 pandemic may be at increased risk of post-traumatic stress and burnout [29]. They may also have difficulty balancing their roles as educators, professional counsellors and supervisors in ways that result in the neglect of their practices [30]. To avoid this situation, some research proposes 
that it is important to highlight the importance of the cultivation of resilience and self-care practices by counsellors [29].

During the period of confinement, many children and adolescents suffered trauma because of the isolation and adversity characteristic of the time-experiences that can trigger much more serious mental health problems [6]. In addition, they were uncertain about their education, future and job opportunities due to the stagnation of studies as a result of the pandemic [5]. The pandemic has forced people out of their comfort zone by radically changing the way they work or study, which has a strong impact on both emotional and mental health [31], and this impact has been much greater among children and adolescents [32]. In several countries, the suicide rate increased during confinement, including among children [33]. According to Slomski [34], online counselling might diminish these thoughts, relieving emotional distress significantly. The world is virtually paralysed by the pandemic, and students are locked in their homes, increasing their scepticism towards the opportunities available to continue their education and achieve employability. Counsellors kept students up to date using technology to steer them away from this job-related pessimism [5].

During confinement, educational counsellors were most likely the only source of mental health support, helping students with their emotional needs [6]. Therefore, counselling was not only the responsibility of the counsellors but also had to be undertaken by a large part of the teaching staff and even by the families of the students themselves, through different guidelines previously established by the educational counsellor [5].

Another sector within the student body that has been affected is that of international students. Many of them were distressed due to discrimination in addition to the aforementioned factors [35]. More specifically, discrimination towards students with Asian traits increased very significantly in some countries such as the United States, among other causes, due to the media [36]. This situation led to increased online reinforcement by educational counsellors to combat oppression in certain countries [35].

The changes driven by COVID-19 are drastic in practically all areas, but within rural schools, the situation is critical. The training of guidance practitioners regarding the use of ICT is a very important factor; however, the training system for guidance practitioners is also very weak [9].

The digital divide is also evident in this situation [12], as groups with a lower socioeconomic level do not have the right conditions for the development of online education [11]. The study by Díez-Gutiérrez and Espinoza [37] concludes that many families in Spain do not have the necessary resources to be able to monitor online education adequately from their homes. It is also evident that inequality is more present in times of crisis, which means an increase in the digital divide. However, the presence of this gap is not something new, it is an inequality that has been established for decades [38].

These students have been affected because the sudden contact with technology on a compulsory basis is new in many cases, making it very difficult for them to keep up with their studies and resulting in an interruption of their education. It is important to familiarise students in this situation with the use of applications and software when providing online guidance and to avoid disruption of their studies as much as possible [5].

The role of counsellors became crucial at this stage to be able to communicate with families who lack sufficient resources for the proper follow-up of online teaching [12]. To be able to play their role properly, counsellors had to start online services and train themselves through online workshops to improve and be updated in terms of digital competence skills and use [39-41]. Regarding the teaching-learning process, the counsellors provided guidelines for families to work with their children at home through different means, from emails to phone calls, if necessary [12].

The publication of links and online resources on school, college or university websites is a very simple and important measure. Such links and resources need to be clear and able to provide easy accessibility to the student [40]. During this period, counsellors 
collected many online resources to provide advice to the educational community and recommendations to families to cope as well as possible with this situation [37].

The shift from face-to-face to online activities has an impact on all students, but especially on vulnerable groups [9]. During the confinement caused by the COVID-19 pandemic, students with disabilities were at risk of not receiving the right measures [11]; therefore, if online resources are not provided for the correct development of teaching and monitoring of their situation, it creates a lack of equity and fairness [40].

In turn, the use of social media has influenced students' academic achievement during confinement. While some research concludes that social networking has negatively affected students' academic achievement, other research concludes that it has positive effects. The fact is that the use of social media has a positive impact on student academic achievement, but if used excessively, it can have a very negative impact [42].

According to a study by Dores et al. [43], the tools most frequently used by educational counsellors during the period of confinement were video calls, social networks and different applications; and the devices most frequently used for these purposes were computers and smartphones.

Examples of the ICT resources most used by counsellors during the period of confinement, divided by different utilities [44,45], are listed in Table 1 .

Table 1. ICT resources classified by category.

\begin{tabular}{ll}
\hline Category & Resources \\
\hline Institutional platforms & $\begin{array}{l}\text { In Spain, depending on each autonomous community, different platforms were used, } \\
\text { such as EducaMadrid or the community's education portal. }\end{array}$ \\
\hline Social media & WhatsApp, Telegram, Remind. \\
\hline Guidance via videoconference & Webex, Zoom, Google Duo, Microsoft Teams, Google Meet, Skype. \\
\hline Tools for daily work & Moodle, Edmodo, Google Classroom, Microsoft Teams. \\
\hline Tools for creating and sharing content & Prezi, Genially, Blogger, Wix, WordPress. \\
\hline Interactive tools & Kahoot, Canva, Padlet, Genially, Microsoft Forms, Edpuzzle. \\
\hline
\end{tabular}

However, even though reacting to the emergence of COVID-19 and its consequent confinement has been challenging, it has meant that new opportunities and ways of carrying out the work of educational guidance have emerged, necessitating a review of these new methods of carrying it out to be prepared to adapt to future challenges [46].

In the study carried out by Maurya et al. [25], counsellors were found to be predisposed to continue with the use of ICT tools in their practice as a secondary way of providing their services, without losing face-to-face counselling.

Nowadays, students are more and more likely to use online counselling. According to Li and Leung [47], students who had counselling before the COVID-19 pandemic were more likely to participate in online counselling services. The technological changes imposed by COVID-19 during the lockdowns may prove to be very positive and beneficial to be used and to be modified and refined as they progress [48].

\section{Materials and Methods}

This scoping review had the aim of analysing the scientific literature on educational guidance using ICTs in times of COVID-19. For this purpose, Systematic Literature Review (SLR) [49] and the PRISMA model (see Figure 1) [50-53] were used as references. The search for bibliographic sources was carried out by exploring articles in both Spanish and English. This search was carried out about the subject matter to obtain the desired information and thus carry out a subsequent analysis. This analysis aimed to draw up a global vision of educational guidance in the COVID-19 times. Articles before 2020 were used as a reference to know the situation of educational guidance and ICT resources before the pandemic. 


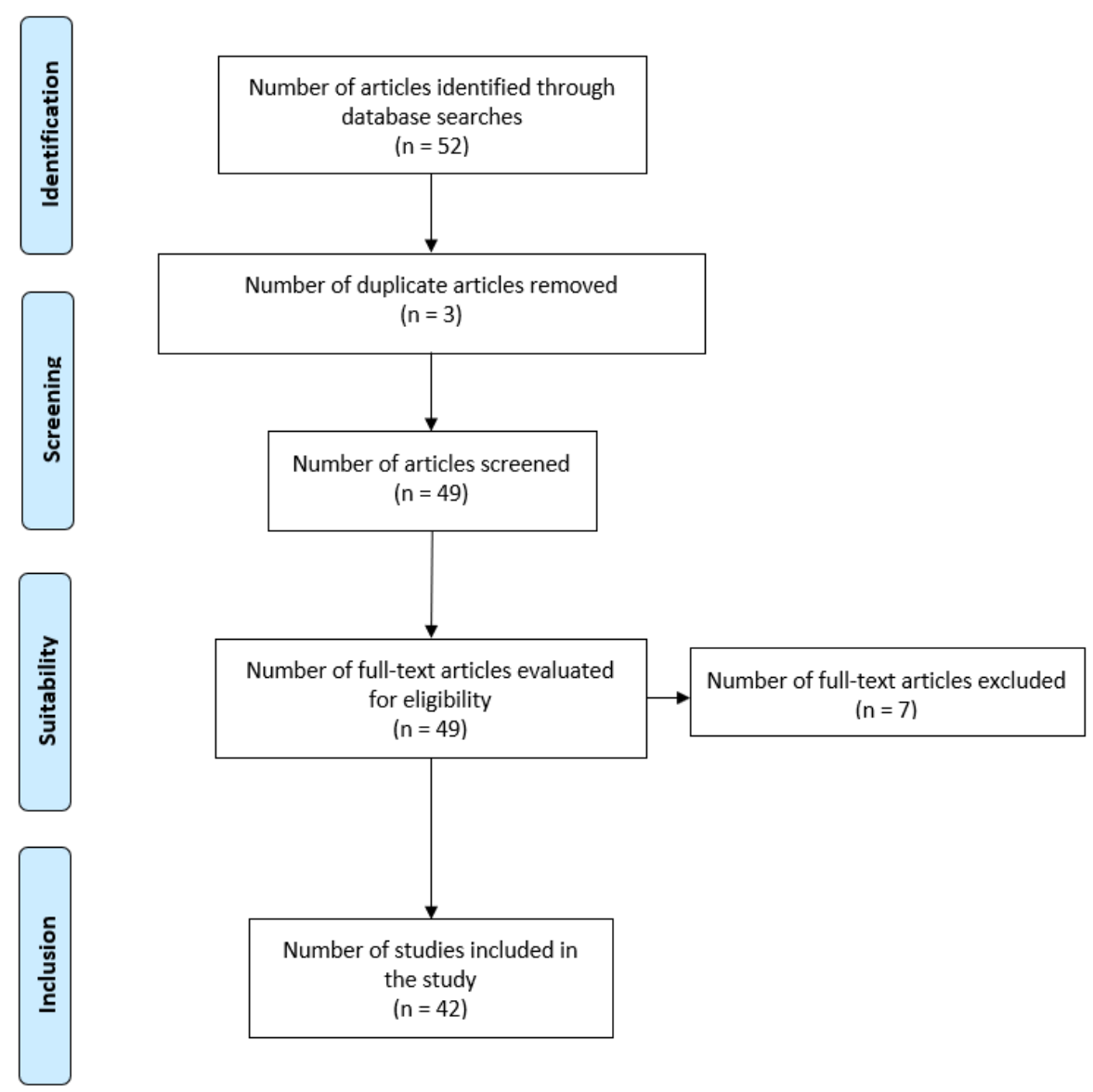

Figure 1. Diagram PRISMA (inspired by [52]).

The research questions (RQs), all concerning educational guidance during COVID-19 pandemic, were as follows:

- RQ1: How many scientific articles were published about educational guidance in COVID-19? (From 2020 and 2021; articles about ICT and educational guidance from 2013 were also taken into consideration, for a wider perspective.)

- RQ2: How many articles were Spanish and how many were from other countries?

- RQ3: How many types of articles were published (research, proposal, or review)?

- RQ4: What was the impact of these publications? (For this we considered CIRC, Integrated Classification of Scientific Journals and amount of Google Scholar citations).

- RQ5: What were the topics and their frequencies?

The following databases were used to search for articles through this process (Figure 1).

- Web of Science-with the keywords counsellor and COVID, 52 results were found, and using the search parameter Education, Educational Research, four articles appeared: three of them in Spanish and one in English. With the keywords counselling and COVID, there were 528 results, and with the use of the search parameter Education, Educational Research, six articles appeared, all in English. From this database, nine articles were finally included in the analysis.

- Scopus-with the keywords school, counsellor and COVID, 267 results were found, and using the parameters social sciences and psychology, there were 158 results. From this database, nine articles were finally included in the analysis.

- ResearchGate-with the keywords COVID-19 and counsellor and using the parameter publications, 15 articles from this database were finally included in the analysis.

- Dialnet - with the keywords orientation and COVID, 102 results were found, and using the parameter psychology and education, 29 articles appeared: 25 of them in Spanish, 
3 in English and 1 in Galician. From this database, nine articles were finally included in the analysis.

After the search for bibliographic sources, the selected articles were read and analysed. The articles were selected based on relevance criteria. For the correct organisation of the information addressed by the articles, a model analysis sheet was used (see Table 2).

Table 2. Model analysis sheet.

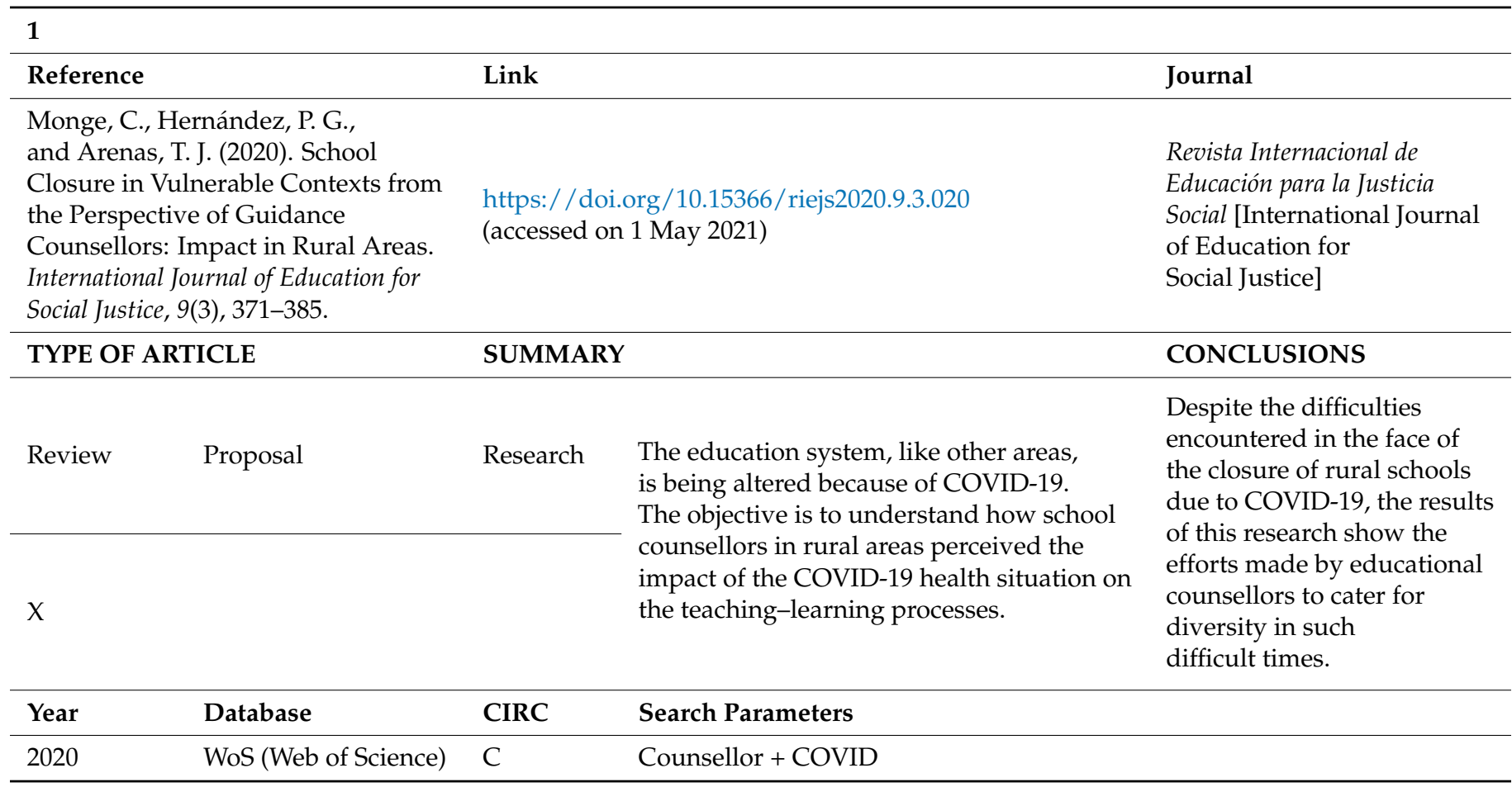

Once the articles were classified, the first step was to read the entire article, in which special importance was given to the summary and the conclusions obtained by the authors of the article. Of these 49 articles, 7 were discarded after reading and corresponding analysis as they did not adequately meet the requirements sought in the subject matter.

Statistical analysis was done from a descriptive point of view, with frequencies and percentiles.

\section{Results}

The results obtained in the process of analysing the literature review were organised according to scientific production, by year, source origin, the CIRC classification of the journals in which the articles were published, the subject matter addressed in the selected articles, the classification of their authors also according to these subjects and, finally, according to the number of citations of the articles in Google Scholar.

\subsection{Scientific Production}

For this systematic literature review, 42 articles were consulted from different databases, both international and national (Spanish). Figure 2 shows the number of articles according to the month of publication for the years 2020 (from March onwards) and 2021 (in the first five months). The bulk of publications were in December 2020, followed by March, June, and October of the same year, with four publications each. It is also worth noting that July 2020 was the only month with no publications (Figure 2). 


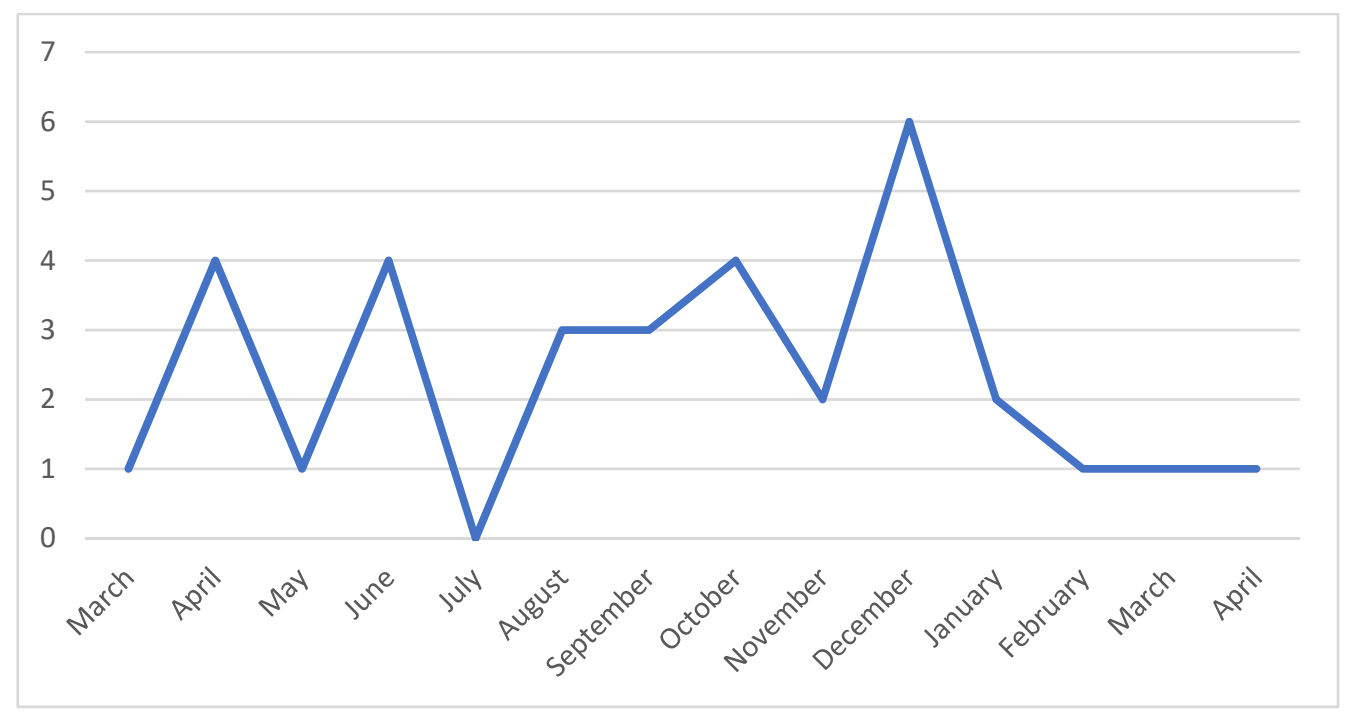

Figure 2. Scientific production by month.

Table 3 shows the scientific production by year and the origin of the journal in which the articles analysed were published, indicating whether they were of national or international origin. The table also includes a classification of these articles according to whether they were proposals, reviews or research.

Table 3. Scientific production by year and type.

\begin{tabular}{|c|c|c|c|c|c|c|}
\hline \multirow{2}{*}{ Year of Publication } & \multicolumn{2}{|c|}{ Journal } & \multicolumn{3}{|c|}{ Type of Article } & \multirow{2}{*}{ TOTAL } \\
\hline & National & International & Proposal & Review & Research & \\
\hline 2021 & 2 & 3 & 0 & 3 & 2 & 5 \\
\hline 2020 & 8 & 20 & 0 & 19 & 9 & 28 \\
\hline 2019 & 0 & 1 & 1 & 0 & 0 & 1 \\
\hline 2018 & 0 & 1 & 0 & 0 & 1 & 1 \\
\hline 2017 & 1 & 0 & 1 & 0 & 0 & 1 \\
\hline 2016 & 0 & 1 & 0 & 0 & 1 & 1 \\
\hline 2015 & 0 & 3 & 0 & 1 & 2 & 3 \\
\hline 2013 & 0 & 2 & 1 & 1 & 0 & 2 \\
\hline TOTAL & 11 & 31 & 3 & 24 & 15 & 42 \\
\hline
\end{tabular}

Concerning the origin of the articles analysed, most of the articles were of international origin, with 31 articles, compared to 11 articles of national origin. About the typology of the articles, systematic literature reviews stood out with 24 articles, followed by research articles with 15 articles. In last place were the proposal articles, with only 3 articles out of the 42 selected for analysis.

\subsection{CIRC Classification and Source Origin}

Table 4 shows both the CIRC classification of the journals in which the articles were published and their origin according to the database from which the articles were obtained: Web of Science, Scopus, ResearchGate or Dialnet.

Starting with the CIRC classification (see Table 5), the Integrated Classification of Scientific Journals (CIRC) aims to classify scientific journals in the Social and Human Sciences according to their quality. This classification is divided into A+ (journals of excellence), A (higher-level journals), B (quality journals that do not reach a high level of internationalisation), $\mathrm{C}$ (second-order journals) and $\mathrm{D}$ (journals that do not have an impact on the scientific community). 
Table 4. CIRC classification and source origin.

\begin{tabular}{|c|c|c|c|c|c|c|c|c|c|}
\hline \multirow{2}{*}{ Year of Publication } & \multicolumn{5}{|c|}{ CIRC Classification } & \multicolumn{4}{|c|}{ Source Origin } \\
\hline & $A+$ & A & B & $\mathrm{C}$ & D & WoS & Scopus & Resear & Dialnet \\
\hline 2021 & 1 & 2 & 1 & 0 & 1 & 2 & 0 & 2 & 1 \\
\hline 2020 & 2 & 1 & 6 & 4 & 15 & 5 & 7 & 9 & 7 \\
\hline 2019 & 0 & 0 & 0 & 1 & 0 & 0 & 1 & 0 & 0 \\
\hline 2018 & 0 & 0 & 0 & 0 & 1 & 0 & 0 & 1 & 0 \\
\hline 2017 & 0 & 0 & 0 & 0 & 1 & 0 & 0 & 0 & 1 \\
\hline 2016 & 0 & 0 & 0 & 0 & 1 & 0 & 0 & 1 & 0 \\
\hline 2015 & 2 & 0 & 0 & 0 & 1 & 1 & 1 & 1 & 0 \\
\hline 2013 & 0 & 0 & 0 & 0 & 2 & 1 & 0 & 1 & 0 \\
\hline TOTAL & 5 & 3 & 7 & 5 & 22 & 9 & 9 & 15 & 9 \\
\hline
\end{tabular}

Table 5. Authors classified by subject.

\begin{tabular}{|c|c|}
\hline \multicolumn{2}{|c|}{ Online Guidance and ICT Resources } \\
\hline Authors & $\begin{array}{l}\text { Ardi and Ifdil (2013) [18]; Budianto et al. (2019) [21]; Hennigan and Goss (2016) [28]; Li et al. [41] (2013); Mishna et al. } \\
\text { (2020) [15]; Slomski (2015) [34]; Suárez (2017) [20]. }\end{array}$ \\
\hline \multicolumn{2}{|c|}{ Online Guidance and ICT Resources during the Pandemic } \\
\hline Authors & $\begin{array}{l}\text { Ahmed and Firdous (2020) [5]; Anandavalli et al. (2020) [35]; Astatke et al. (2021) [42]; Delgado (2020) [3]; Dores et al. } \\
\text { (2020) [43]; Foon et al. (2020) [27]; Garcia (2020) [38]; Garoz and Resina (2021) [12]; Litam et al. (2021) [29]; } \\
\text { Manco-Chavez et al. (2020) [17]; Maurya et al. (2020) [25]; Meleo-Erwin et al. (2020) [40]; Moreno (2020) [1]; O'Connor } \\
\text { (2020) [10]; Pincus et al. (2020) [6]; Rodríguez et al. (2020) [45]; Sanz (2020) [44]; Shah et al. (2020) [48]; Situmorang } \\
\text { (2020) [14]; Tandon (2020) [32]; Vostanis and Bell (2020) [46]. }\end{array}$ \\
\hline \multicolumn{2}{|c|}{ Status of the Educational Counsellor } \\
\hline Authors & Abdillah et al. (2020) [8]; Beidoglu et al. (2015) [16]; Košir et al. (2021) [26]; Mason et al. (2018) [22]. \\
\hline \multicolumn{2}{|c|}{ Situation of Families during the Pandemic } \\
\hline Authors & $\begin{array}{l}\text { Balachandran et al. (2020) [33]; Cabrera (2020) [31]; Cifuentes-Faura (2020) [4]; Díez-Gutiérrez and Espinoza (2021) [37]; } \\
\text { Haleemunnissa et al. (2020) [39]; Li and Leung (2020) [47]; Litam (2020) [29]; Monge et al. (2020) [9]; Murillo and Duk } \\
\text { (2020) [11]; Wise (2021) [7]. }\end{array}$ \\
\hline
\end{tabular}

The CIRC analysis (see Figure 3) shows that most articles meet criterion D, with 22 articles. According to this classification, group D includes not only journals that do not have an impact on the scientific community but also journals that are not indexed. As already mentioned in Table 1, most of the articles were of international origin; and 17 of the 42 articles analysed were not included in the CIRC classification. As CIRC is a Spanish classification, and these 17 articles are of foreign origin, they were included in group D of the classification.

The next most frequently met criterion in this analysis was group $B$, with seven items, closely followed by the $\mathrm{A}+$ and $\mathrm{C}$ classification, with five items each. Finally, the classification that was least repeated in these articles was that of group A, with only three articles.

About the origin of the articles in the different databases (see Table 5), the database from which the most articles were obtained was ResearchGate, with 15 articles; compared to the articles obtained from Web of Science, Scopus and Dialnet, with 9 articles obtained from each of these databases.

In all databases, the bulk of the publications (see Figure 4) were in the year 2020, with nine publications in ResearchGate, seven in Dialnet and Scopus, and five in Web of Science. This is obviously because 2020 was the year in which the pandemic emerged, so the articles were mostly written in that year. The rest of the years had constant values of publications, around one or none. These years correspond to the articles used as a reference to find out how the situation of educational guidance with ICT resources already was before the pandemic. 


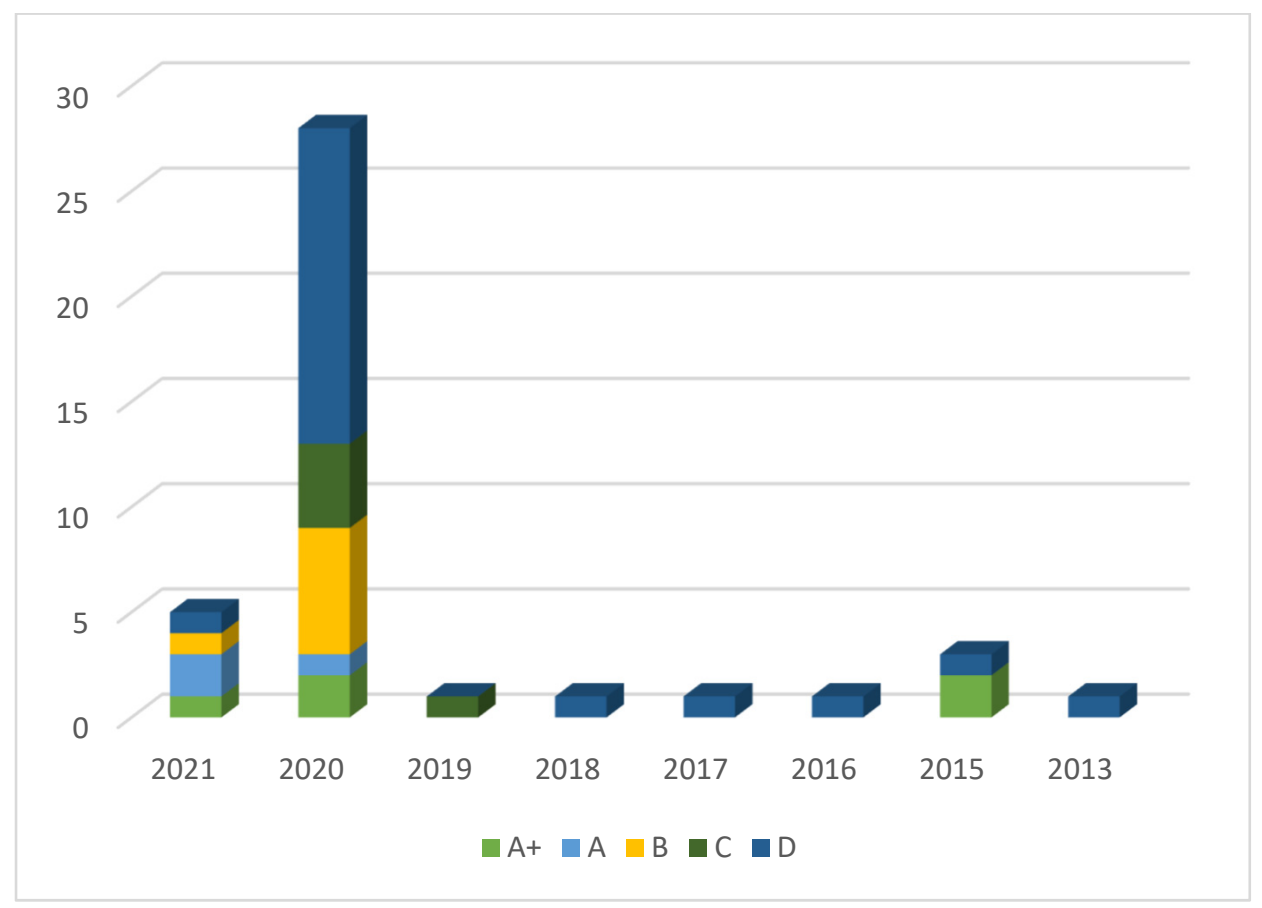

Figure 3. Publications by year according to the CIRC classification.

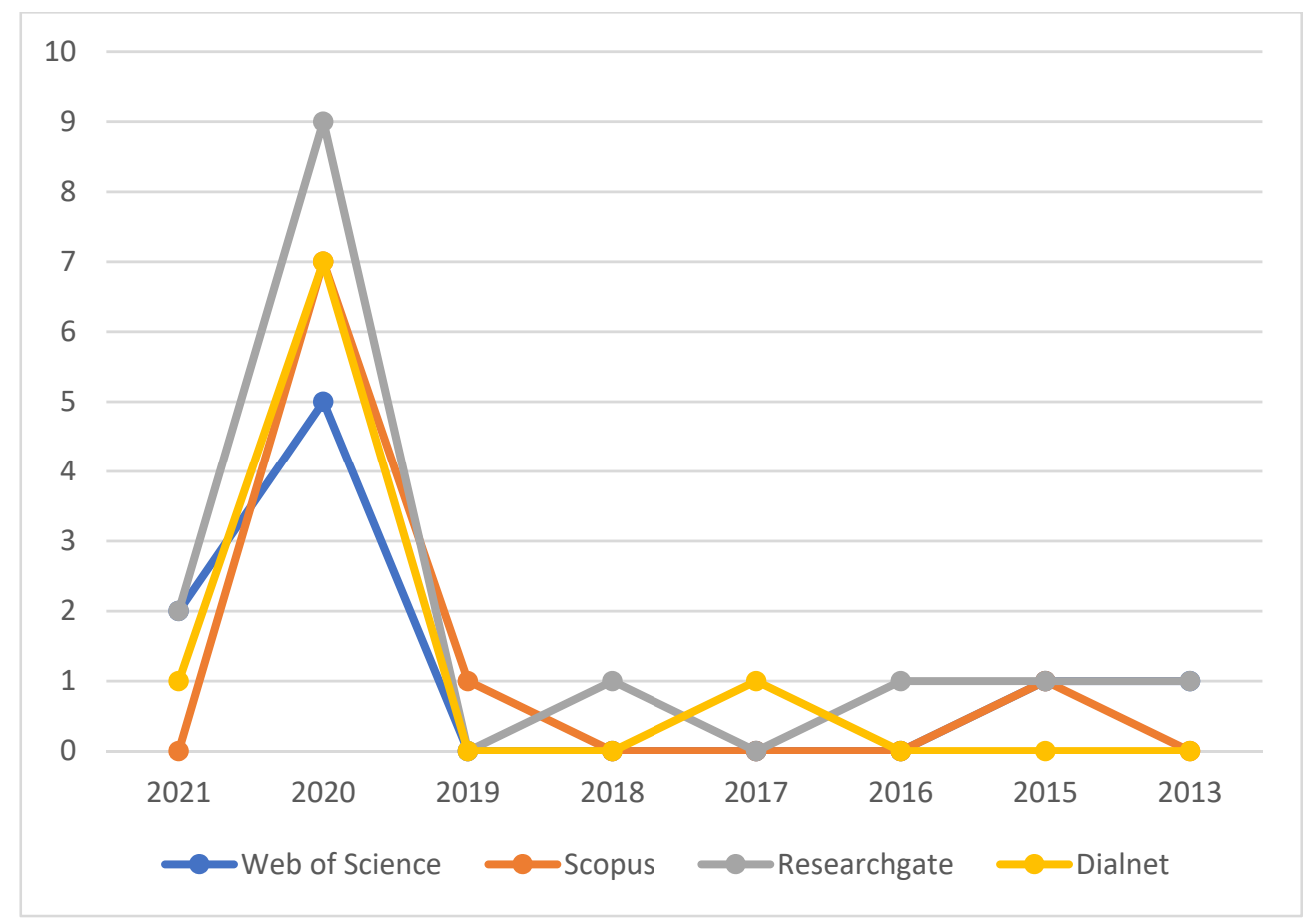

Figure 4. Scientific production by year according to the database.

\subsection{Topics}

The selected articles were categorised according to the following four topics (Figure 5):

- Online guidance and ICT resources: this theme encompasses articles that include resources for the development of online educational guidance and ICT resources focused on some aspect of educational guidance before the onset of the COVID19 pandemic.

- $\quad$ Online guidance and ICT resources during the pandemic: this theme encompasses articles that include the resources that educational counsellors had to resort to to 
be able to continue with the development of online educational guidance and ICT resources focused on some aspect of educational guidance.

- The situation of the educational counsellor during the pandemic: this topic deals with articles that reflect the situation that educational counsellors had to face, such as adapting very quickly to a completely online situation and the consequences that this situation had for them, both emotionally and physically.

- The situation of families during the pandemic: this theme includes articles on how families had to cope with online teaching and the consequences for them of the sudden adoption of this mode of teaching based on different factors.

As can be seen in Figure 5, most of the articles fell under the topic "Online counselling and ICT resources during the pandemic", with half of the total number of articles consulted. The next most frequent categories were "Situation of families" and "Online counselling and ICT resources", with $24 \%$ and $17 \%$, respectively. Finally, the least frequent topic was "The situation of the educational counsellor during the pandemic", with only $9 \%$ of the total. Table 5 lists the authors of the articles consulted, classified according to the topics mentioned above.

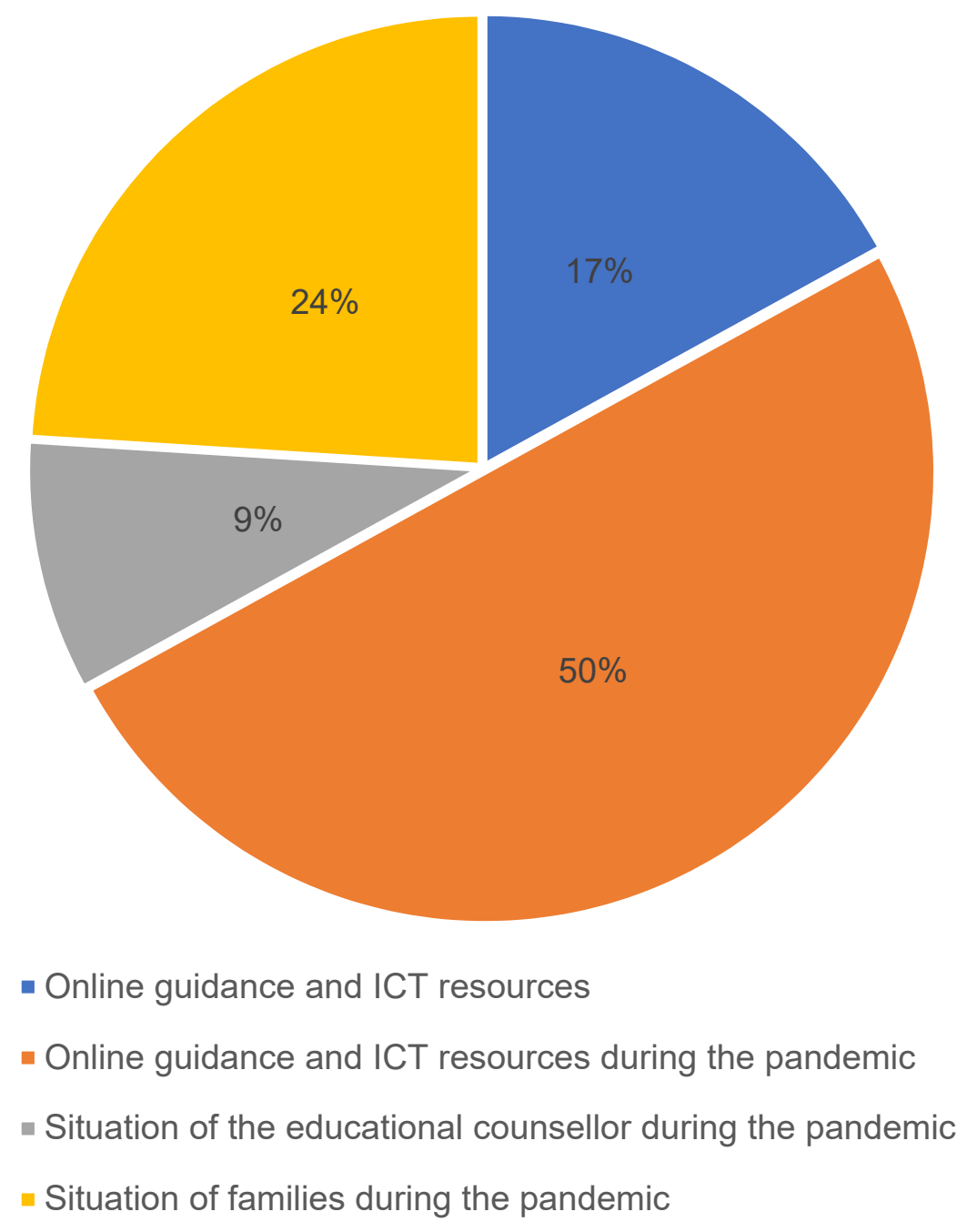

Figure 5. Topics of the articles.

Within the topic of "Online guidance and ICT resources", it can be observed that all but one of the articles were from before 2020. This is because they were proposals on how to use ICT resources for the development of guidance in a routine way without exceptional 
situations such as a pandemic. On the topic of "Online guidance and ICT resources during a pandemic", it is clear that all the articles were older than 2020, as they cover the ICT resources that guidance practitioners had to use to carry out their functions.

The topic "The situation of the educational counsellor" had two articles before 2020, as they dealt with the situation of the educational counsellor and their digital competence. The articles from the years 2020 and 2021, additionally addressed how the sudden shift to fully online teaching affected the counsellors. Finally, the category "Situation of families during the pandemic" also had articles exclusively from the years 2020 and 2021, as they reflected the situation of many families in this situation.

\subsection{Number of Citations in Google Scholar}

Table 6 shows the authors of the articles (2020-2021, incomplete) together with the number of citations of these articles in Google Scholar. They have not had a great impact within the scientific community, or at least for the moment, as the subject matter they deal with is still very recent.

Table 6. Citations (Google Scholar).

\begin{tabular}{|c|c|c|}
\hline Year & Authors & Google Scholar Citations \\
\hline \multirow{28}{*}{2020} & Abdillah et al. & 1 \\
\hline & Ahmed and Firdous & 1 \\
\hline & Anandavalli et al. & 4 \\
\hline & Balachandran et al. & 2 \\
\hline & Cabrera & 47 \\
\hline & Cifuentes-Faura & 25 \\
\hline & Delgado & 0 \\
\hline & Dores et al. & 8 \\
\hline & Foon et al. & 4 \\
\hline & Garcia & 7 \\
\hline & Haleemunissa et al. & 4 \\
\hline & Košir et al. & 5 \\
\hline & Li and Leung & 11 \\
\hline & Litam & 18 \\
\hline & Manco-Chavez et al. & 1 \\
\hline & Maurya et al. & 2 \\
\hline & Meleo-Erwin et al. & 4 \\
\hline & Monge et al. & 0 \\
\hline & Moreno & 0 \\
\hline & Murillo and Duk & 53 \\
\hline & O'Connor & 1 \\
\hline & Pincus et al. & 1 \\
\hline & Rodriguez et al. & 7 \\
\hline & Sanz & 10 \\
\hline & Shah et al. & 39 \\
\hline & Situmorang & 3 \\
\hline & Tandon & 103 \\
\hline & Vostanis and Bell & 13 \\
\hline \multirow{5}{*}{2021} & Astatke et al. & 0 \\
\hline & Díez-Gutiérrez and Espinoza & 0 \\
\hline & Garoz and Resin & 0 \\
\hline & Litam et al. & 2 \\
\hline & Wise & 34 \\
\hline
\end{tabular}

In this study, a total of 604 citations were found in Google Scholar (see Figure 6). Most of the citations belonged to the year 2020, with 374 citations collected on the platform. 


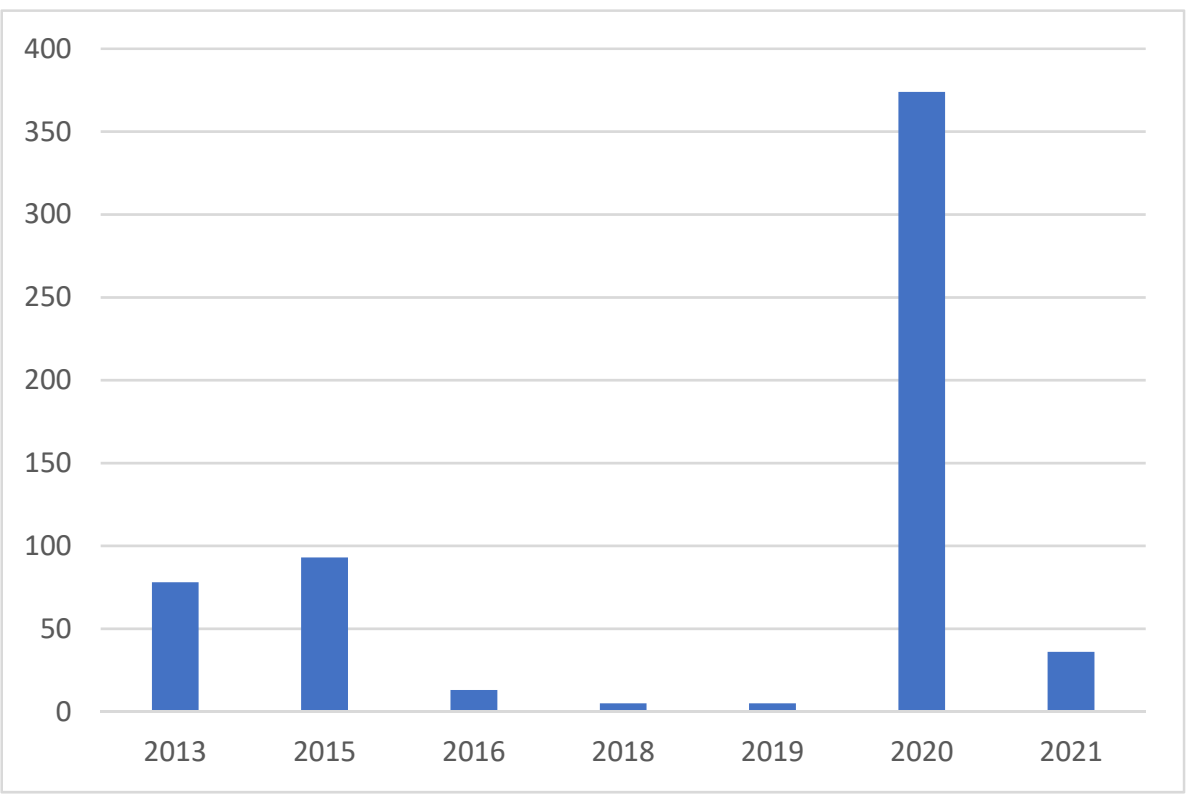

Figure 6. Number of citations in Google Scholar by year.

Of particular interest are the articles by Tandon (2020) [32] and Wise (2021) [7], with 103 and 34 citations, respectively. The latter article was published in March of this year and already has numerous citations in only two months.

\section{Discussion}

Among the reviewed articles, there were proposals, reviews, and research. It is evident that, considering this topic, systematic literature reviews stood out from the rest, with 24 articles out of the 42 selected.

Nowadays, there are numerous articles that address this issue, and half of the reviewed articles meet at least criterion C of the CIRC classification. However, the other half are considered not relevant because they are journals not indexed in the CIRC classification.

Regarding the use of online resources, while it is true that in 2020 this topic grew exponentially, it was not a new topic that arose that year [14], since $17 \%$ of the articles addressed the use of ICT in educational guidance before the onset of the pandemic. This is because the use of ICT resources in educational guidance supposes the strengthening of the role of the counsellor [19], because it allows optimisation of the development of their functions [18]. Based on these results, ICT resources have become essential for the development of educational guidance [16].

However, many educational counsellors did not have the necessary training, knowledge, or resources to be able to continue with their roles. As Monge et al. [9] said, this may be due to the lack of knowledge or confidence in the application of ICT resources. As a result, they had to learn in a very short time to try to become fluent in ICT resources. With the appropriate level of digital competence, the resources used by counsellors become more meaningful to the students [23].

Even though this topic had been dealt with before the year 2020, this year had more publications and citations. Of the 42 articles consulted, 28 were published in 2020, and regarding bibliographic citations, the articles consulted were cited 374 times in Google Scholar.

The pandemic situation had a great impact on guidance work, as the functions of the guidance counsellor had to be adapted and expanded; therefore, there was an imbalance in their established functions [30], while others had to be reduced or even dispensed with. The impact on guidance work could be seen as mainly negative; however, the fact that it has jump-started the mandatory use of ICT has opened a world of great possibilities within educational guidance. 
The main advantage of this study is the topicality of the subject, as there is more and more information on the subject every day and we are still suffering the effects of the pandemic. However, this is also its main limitation. As this is such a new topic, most of the existing articles have not yet been officially published, so it was quite difficult to find them at first. To solve this, it was necessary to resort to other databases such as ResearchGate, requesting these articles from their authors for use in this study.

Another limiting factor is the specification of the use of ICT in educational guidance. Most of the studies and articles had, as their main theme, the situation that educational institutions, in general, had to experience, focusing mainly on the work of teachers. It seems that it is still too early to find many scientific articles with a specific focus on educational guidance. However, although it is a recent topic, due to its special relevance in our society, it can be said that there are quite a few articles on this topic, and that, moreover, they have been cited with a high frequency as can be seen in the results of the work. An additional limitation of this research is language-searching of keywords for articles in English and Spanish. With English being main scientific language, Spanish may have introduced a deviation from a more global perspective, with 11 articles in Spanish out of the 42 articles analysed. One of the sources, Dialnet, is mainly a database for scientific documents in Spanish.

As a future line of research on this same topic, we suggest revisiting the existing scientific articles on this same subject, as more time will have passed since this very complex event for our society and the bibliography will, therefore, be more extensive and published in different quality journals.

In addition to that, another interesting line of research is the resources used. In this research, it has been possible to see the resources that counsellors had to use in an emergency, and most of the resources were based on maintaining constant communication with students. With a considerable margin of time, it will be feasible to analyse the ICT resources that educational counsellors have integrated into their day-to-day work after the return to face-to-face work.

To collect all this information, the best option would be to research by surveying a sufficiently large sample of guidance practitioners who served during the confinement and who are still practicing. The purpose of such research would be to check whether this period of sudden adaptation to the use of ICTs has meant a step forward in the integration of ICTs in their professional practice and to find out their perception of their use. Ideally, this research would also investigate the possible existence of health problems because of the levels of stress to which the counsellors were subjected during the period of confinement.

\section{Conclusions}

To sum up, from 2020 to 2021, 33 articles related to counselling during the COVID-19 pandemic were published. For a wider perspective, articles from previous years were also taken into consideration, finding nine articles about this topic (so, 42 articles were analysed).

Of these articles, 11 of them were Spanish, while the other 31 were from other countries. In addition, according to the typology of the articles, 24 reviews, 15 research works and only 3 proposals were consulted.

Regarding the impact of the publications, according to the CIRC classification they did not have a great impact, since most of the articles belonged to the D category, although this was due to the fact that many journals were not indexed in the CIRC classification but were indexed on similar bases. However, it was a topic with numerous citations in Google Scholar, with 374 in the year 2020 alone.

The topics approached by the articles, ordered by the highest percentage of frequencies, were "Online guidance and ICT resources during the pandemic" (50\%), "Situation of families during the pandemic" (24\%), "Online guidance and ICT resources before the onset of COVID-19" (17\%) and "Situation of the educational counsellor during the pandemic" (9\%).

Considering the global situation provoked by COVID-19, negative effects of the pandemic on practically all areas of society have been evident. It was a situation that no 
one expected and that caught many people unawares. It meant a radical change in the way we all live our lives, exchanging face-to-face presence for the use of ICTs to be able to carry on with our lives and our work obligations.

As for many, this was also a radical change for educational institutions. Our education system is based on students being in the classroom, and online education has never been an option in schools and colleges, so it was a change that most educational institutions were not prepared for.

This sudden shift from fully face-to-face to fully online teaching led to organisational chaos, especially at the beginning of the pandemic. Many institutions even lacked online platforms for contacting students' families to ensure that they could continue to monitor education despite the situation. Faced with this problem, the work of the educational counsellor became essential.

The integration of ICT in guidance work is a natural step that will happen sooner or later. ICT is all around us, and we interact with it constantly, and more and more fields are benefiting from its use by integrating it in practically all their functions. It involves a set of tools that help us in our daily lives, and the field of educational guidance is no exception. There are more and more resources on the web, and due to the consequences of the COVID-19 pandemic, they have increased significantly. These are resources with great potential that through their gradual implementation will gradually improve their relevance and usefulness.

Author Contributions: Conceptualization, I.M.-C. and S.S.-S.; methodology, I.M.-C. and M.G.-d.-P.; formal analysis, I.M.-C.; investigation, I.M.-C. and S.S.-S.; writing-original draft preparation, I.M.-C. and S.S.-S.; writing-review and editing, I.M.-C. and M.G.-d.-P.; supervision, M.G.-d.-P. All authors have read and agreed to the published version of the manuscript.

Funding: This research received no external funding.

Informed Consent Statement: Not applicable.

Acknowledgments: To Juan Grande-Aguilar, as translation reviewer.

Conflicts of Interest: The authors declare no conflict of interest.

\section{References}

1. Moreno, A.P. COVID-19, una Radiografía de la Pandemia. [COVID-19, an X-ray of the Pandemic]. Bol. IEEE 2020, 19, 692-733.

2. Gobierno de España. Real Decreto 463/2020, de 14 de Marzo, Por el Que se Declara el Estado de Alarma Para la Gestión de la Situación de Crisis Sanitaria Ocasionada Por el COVID-19; [Royal Decree 463/2020 of 14th March Declaring a State of Alarm for the Management of the Health Crisis Situation Caused by COVID-19]; BOE-A-2020-3692; BOE: Madrid, Spain, 2020. Available online: https: / / bit.ly/3bZDDnD (accessed on 1 May 2021).

3. Delgado, J.L.G. La apuesta Por el Teletrabajo: Una Realidad Social Que se Impone. Ventajas e Inconvenientes. Rev. Derecho Segur. Soc. Laborum 2020, 25, 253-266.

4. Cifuentes-Faura, J. Consecuencias en los niños del cierre de escuelas por COVID-19: El papel del gobierno, profesores y padres. [Consequences on children of school closures by COVID-19: The role of government, teachers and parents]. Rev. Int. Educ. Para Justicia Soc. 2020, 9, 1-12. [CrossRef]

5. Ahmed, A.; Firdous, H. The Transformational Effects of COVID-19 Pandemic on Guidance and Counseling. Int. J. Adv. Res. Innov. Ideas Educ. 2020, 6, 172-179.

6. Pincus, R.; Hannor-Walker, T.; Wright, L.; Justice, J. COVID-19's Effect on Students: How School Counselors Rise to the Rescue. NASSP Bull. 2020, 104, 241-256. [CrossRef]

7. Wise, J. COVID-19: European countries suspend use of Oxford-AstraZeneca vaccine after reports of blood clots. BMJ 2021, 372, n699. [CrossRef] [PubMed]

8. Abdillah, H.; Setyosari, P.; Lasan, B.B.; Muslihati, M. The acceptance of school counselor in the use of ICT during school from home in the COVID-19 era. J. Educ. Gift. Young Sci. 2020, 8, 1569-1582. [CrossRef]

9. Monge, C.; Hernández, P.G.; Arenas, T.J. Cierre de escuelas en contextos vulnerables desde la perspectiva de los orientadores: Impacto en zonas rurales. [School closure in vulnerable contexts from the perspective of guidance counsellors: Impact in rural areas]. Rev. Int. Educ. Para Justicia Soc. 2020, 9, 371-385. [CrossRef]

10. O'Connor, M. School counselling during COVID-19: An initial examination of school counselling use during a 5-week remote learning period. Pastor. Care Educ. 2020. [CrossRef] 
11. Murillo, F.J.; Duk, C. El COVID-19 y las brechas educativas. [COVID-19 and educational gaps]. Rev. Latinoam. Educ. Inclusiva 2020, 14, 11-13. [CrossRef]

12. Sanjuan, J.Á.G.; Jiménez, C.R. ¿Cómo han respondido los centros educativos ante la pandemia del COVID-19? [How Have Schools Responded to the COVID-19 Pandemic?]. Aularia 2021, 10, 45-52.

13. Harrichand, J.J.; Thomas, J.C.; Mwendwa, J.M.; DiLella, N.M. Leadership and burnout: An analysis of counselor educators in CACREP-accredited programs in the United States. J. Couns. Leadersh. Advocacy 2021, 8, 56-70. [CrossRef]

14. Situmorang, D.D.B. Online/Cyber Counseling Services in the COVID-19 Outbreak: Are They Really New? J. Pastor. Care Couns. 2020, 74, 166-174. [CrossRef]

15. Mishna, F.; Bogo, M.; Sawyer, J.L. Cyber counseling: Illuminating benefits and challenges. Clin. Soc. Work. J. 2015, 43, 169-178. [CrossRef]

16. Beidoglu, M.; Dinçyürek, S.; Akıntug, Y. The opinions of school counselors on the use of information and communication technologies in school counseling practices: North Cyprus schools. Comput. Hum. Behav. 2015, 52, 466-471. [CrossRef]

17. Manco-Chavez, J.A.; Uribe-Hernandez, Y.C.; Buendia-Aparcana, R.; Joaquin, J.; Vertiz-Osores, S.D.I.A.; Rengifo-Lozano, R.A. Integration of ICTS and Digital Skills in Times of the Pandemic COVID-19. Int. J. High. Educ. 2020, 9, 11-20. [CrossRef]

18. Ardi, Z.; Ifdil, I. Konseling Online Sebagai Salah Satu Bentuk Pelayanan E-konseling. [Online Counseling As A Format of E-counseling Services]. J. Konseling Dan Pendidik. 2013, 1, 15-22. [CrossRef]

19. Sánchez, M.F. Orientación Profesional y Personal; [Professional and Personal Guidance]; UNED: Madrid, Spain, 2017.

20. Suárez, J.J. Mywaypass.com: Una Plataforma de Orientación Para Ayudar a los Jóvenes a Decidir Sobre su Futuro. [Mywaypass.com: A Guidance Platform to Help Young People Decide on Their Future]. Rev. AOSMA 2017, 24, 28-33.

21. Budianto, A.; Aziz, A.; Hidayah, N. ICT application in cyber counseling as a teacher accelerator with optimizing WhatsApp based mobile computing. J. Phys. 2019, 375, 12006. [CrossRef]

22. Mason, E.; Griffith, C.; Belser, C. School Counselors' Use of Technology for Program Management. Prof. Sch. Couns. 2018, 22, 1-11. [CrossRef]

23. Julius, A.; Fahriza, I.; Wulandari, P. Digital literacy as a school counselor competence in the development of media in guidance services. J. Penelit. Bimbing. Dan Konseling 2020, 5, 10106. [CrossRef]

24. Suryahadikusumah, A.R.; Nadya, A. Digital Literacy and Innovation for Guidance and Counseling Program. In 2nd International Seminar on Guidance and Counseling; Springer: New York, NY, USA, 2019; pp. 190-195. [CrossRef]

25. Maurya, R.K.; Bruce, M.A.; Therthani, S. Counselors' Perceptions of Distance Counseling: A National Survey. J. Asia Pac. Couns. 2020, 10, 1-22. [CrossRef]

26. Košir, K.; Dugonik, Š.; Huskić, A.; Gračner, J.; Kokol, Z.; Krajnc, Ž. Predictors of perceived teachers' and school counselors' work stress in the transition period of online education in schools during the COVID-19 pandemic. Educ. Stud. 2020. [CrossRef]

27. Foon, L.W.; Zainudin, Z.N.; Yusop, Y.M.; Othman, W.N.W. E-counselling: The intention, motivation and deterrent among school counselors. Univ. J. Educ. Res. 2020, 8, 44-51. [CrossRef]

28. Hennigan, J.; Goss, P.S. UK secondary school therapist's online communication with their clients and future intentions. Couns. Psychother. Res. 2016, 16, 149-160. [CrossRef]

29. Litam, S.D.A.; Ausloos, C.D.; Harrichand, J.J.S. Stress and resilience among professional counselors during the COVID-19 pandemic. J. Couns. Dev. 2021,99.

30. Harrichand, J.J.; Litam, S.D.A.; Ausloos, C.D. Infusing self-care and wellness into CACREP curricula: Pedagogical recommendations for counselor educators and counselors during COVID-19. Int. J. Adv. Couns. 2021, 43, 372-385. [CrossRef]

31. Cabrera, E.A. Actividad física y efectos psicológicos del confinamiento por COVID-19. [Physical activity and psychological effects of COVID-19 lockdown]. Rev. INFAD Psicol. J. Dev. Educ. Psychol. 2020, 2, 209-220. [CrossRef]

32. Tandon, R. COVID-19 and mental health: Preserving humanity, maintaining sanity, and promoting health. Asian J. Psychiatry 2020, 51, 102256. [CrossRef]

33. Balachandran, A.K.; Alagarsamy, S.; Mehrolia, S. Suicide among children during COVID-19 pandemic: An alarming social issue. Asian J. Psychiatry 2020, 54, 102420. [CrossRef]

34. Slomski, A. Online therapy reduces suicide ideation in medical interns. JAMA 2015, 314, 2608. [CrossRef]

35. Anandavalli, S.; Harrichand, J.J.; Litam, S.D.A. Counseling international students in times of uncertainty: A critical feminist and bioecological approach. Prof. Couns. 2020, 10, 365-375. [CrossRef]

36. Litam, S.D.A. “Take Your Kung-Flu Back to Wuhan": Counseling Asians, Asian Americans, and Pacific Islanders with Race-Based Trauma Related to COVID-19. Prof. Couns. 2020, 10, 144-156. [CrossRef]

37. Díez-Gutiérrez, E.J.; Espinoza, K.G. Education online in lockdown: Limits and possibilities. The vision of families in Spain. Equal. Divers. Incl. 2020. [CrossRef]

38. García, E.S. Reflexiones Sobre la Educación Telemática en Tiempos de Coronavirus. [Reflections on Telematic Education in Times of Coronavirus]. Rev. AOSMA 2020, 28, 13-19.

39. Haleemunnissa, S.; Didel, S.; Swami, M.K.; Singh, K.; Vyas, V. Children and COVID19: Understanding impact on the growth trajectory of an evolving generation. Child. Youth Serv. Rev. 2020, 120, 105754. [CrossRef] [PubMed]

40. Meleo-Erwin, Z.; Kollia, B.; Fera, J.; Jahren, A.; Basch, C. Online support information for students with disabilities in colleges and universities during the COVID-19 pandemic. Disabil. Health J. 2020, 14, 101013. [CrossRef] 
41. Li, P.; Jaladin, R.A.M.; Abdullah, H.S. Understanding the Two Sides of Online Counseling and their Ethical and Legal Ramifications. Procedia-Soc. Behav. Sci. 2013, 103, 1243-1251. [CrossRef]

42. Astatke, M.; Weng, C.; Chen, S. A literature review of the effects of social networking sites on secondary school students' academic achievement. Interact. Learn. Environ. 2021. [CrossRef]

43. Dores, A.R.; Geraldo, A.; Carvalho, I.P.; Barbosa, F. The use of new digital information and communication technologies in psychological counseling during the COVID-19 pandemic. Int. J. Environ. Res. Public Health 2020, 17, 7663. [CrossRef]

44. Sanz, J.I.M. Uso de TIC en Orientación Educativa en Tiempos de COVID-19. [Use of ICT in Educational Guidance in Times of COVID-19]. Rev. AOSMA 2020, 28, 88-91.

45. Rodríguez, L.O.; Díaz, M.I.C.; Pandiella, R.L. Herramientas Digitales Para la Comunicación, la Tele-Docencia y la Tele-Orientación Educativa en Tiempos de COVID-19; [Digital Tools for Communication, Tele-Teaching and Tele-Educational Guidance in Times of COVID-19]. Rev. AOSMA 2020, 28, 92-103.

46. Vostanis, P.; Bell, C.A. Counselling and psychotherapy post-COVID-19. Couns. Psychother. Res. 2020, 20, 389-393. [CrossRef] [PubMed]

47. Li, T.M.; Leung, C.S. Exploring student mental health and intention to use online counselling in Hong Kong during the COVID-19 pandemic. Psychiatry Clin. Neurosci. 2020, 74, 564-565. [CrossRef]

48. Shah, S.; Diwan, S.; Kohan, L.; Rosenblum, D.; Gharibo, C.; Soin, A.; Sulindro, A.; Nguyen, Q.; Provenzano, D.A. The technological impact of COVID-19 on the future of education and health care delivery. Pain Physician 2020, 23, 367-380. [CrossRef]

49. Kitchenham, B.; Brereton, O.P.; Budgen, D.; Turner, M.; Bailey, J.; Linkman, S. Systematic literature reviews in software engineering-a systematic literature review. Inf. Softw. Technol. 2009, 51, 7-15. [CrossRef]

50. Arksey, H.; O’Malley, L. Scoping studies: Towards a methodological framework. Int. J. Soc. Res. Methodol. 2005, 8, 19-32. [CrossRef]

51. Grant, M.J.; Booth, A. A typology of reviews: An analysis of 14 review types and associated methodologies. Health Inf. Libr. J. 2009, 26, 91-108. [CrossRef] [PubMed]

52. Moher, D.; Liberati, A.; Tetzlaff, J.; Altman, D.G. Preferred reporting items for systematic reviews and Meta Analyses: The PRISMA Statement. PLoS Med. 2009, 6, e1000097. [CrossRef]

53. Page, M.J.; McKenzie, J.E.; Bossuyt, P.M.; Boutron, I.; Hoffmann, T.C.; Mulrow, C.D.; Shamseer, L.; Tetzlaff, J.M.; Moher, D. Updating guidance for reporting systematic reviews: Development of the PRISMA 2020 statement. J. Clin. Epidemiol. 2021, 134, 103-112. [CrossRef] [PubMed] 